\title{
Review of Diagnosis and Management of Scrotal Trauma with a Case Report
}

\author{
Devendra K Prajapati ${ }^{1}$, Kapil Rampal ${ }^{1}$, Jyoti M Prajapati ${ }^{2}$ \\ 1Senior Resident, Department of Surgery, Deendayal Upadhyay Hospital, New Delhi, India. \\ ${ }^{2}$ Scholar in Computer Application
}

\begin{abstract}
Scrotal trauma is a rare surgical emergency. Blunt trauma scrotum is a common mode of scrotal injury which may result in testicular rupture, haematocele, testicular dislocation and hematoma. Testicular injuries are managed both conservatively as well as surgically. Surgical exploration becomes a must in case of testicular rupture and large haematoceles.
\end{abstract}

Keywords: Scrotum, Testis, Rupture, Haematoma, Trauma.

Article History:

Received: 29-04-2016, Revised: 02-05-2016, Accepted: 26-05-2016

\section{INTRODUCTION AND ETIOPATHOGENESIS}

Scrotal trauma is a rare surgical emergency accounting for less than $1 \%$ of all traumatic injuries, largely because of its safe anatomical location and mobility. The injuries are predominantly more prevalent in 15-40 years of age group ${ }^{1}$. However, $5 \%$ of trauma patients are less than 10 years old (Monga and Hellstrom 1996). There are various mechanisms of scrotal trauma, of which blunt trauma is the commonest form.

Blunt trauma scrotum contributing to $80 \%$ scrotal injuries is usually caused by sports like road bicycling, horse-back riding, motorcycle riding, especially on bikes with a dominant gas tank (Leibovitch and Mor 2005). Blunt testicular trauma has been reported amongst in-line hockey skating and rugby players (Frauscher et al. 2001). Motor vehicle accidents and direct physical assault also contribute to scrotal injuries ${ }^{2}$.

The right testis is more likely to get injured than the left one, because it is more likely to be trapped against the pubis bone and the inner thigh'.

Blunt trauma due to motor vehicle accident and physical assault has been reported to have a prevalence of $9-17 \%{ }^{3}$.

The blunt trauma injury caused by a blow forces the testicle against the thigh or pubis and results in intra-testicular bleeding. The tunica albuginea is believed to get ruptured only when the trauma force exceeds $50 \mathrm{~kg}^{4}$.

If the bleeding remains within the tunica vaginalis, haematocele results. But when the tunica vaginalis gets torn due to high intratesticular pressure and bleeding, scrotal hematoma forms and presents as an enlargement of the scrotum.

Penetrating trauma contributes to remaining $20 \%$ of scrotal injuries and is caused by firearm (commonest), stab, animal hit and self-inflicted injuries.

Thermal and degloving injuries- are the rarest cause of scrotal injuries. In degloving injury scrotal skin is sheared off, and it often requires skin grafting ${ }^{5}$.
${ }^{*}$ Correspondence to:

Dr. Devendra K Prajapati, WZ 423 A Nanakpura Harinagar, New Delhi.

Email: dr.dev1982@gmail.com

\begin{tabular}{|l|r|}
\hline \multicolumn{2}{|c|}{ Access this article online } \\
\hline Website: & Quick Response code \\
www.jmmrp.com & \\
\hline DOI: & \\
10.21276/ijmrp.2016.2.3.043 & \\
\hline
\end{tabular}

\section{SCROTAL ANATOMY}

The scrotum having two compartments is separated by the midline septum, which is called median raphe. Each compartment of the scrotum contains a spermatic cord, testis, and epididymis. The wall of scrotum is formed of the several layers, namely: Skin, superficial fascia, Dartos muscle, external spermatic fascia, cremasteric fascia and the Internal spermatic fascia (superficial to deep). The testes is covered by tunica vaginalis, which has two layers. The layer towards the scrotal wall is the parietal layer, and the layer overlying the testis and epididymis is the visceral layer. The tunica vaginalis covers the testis and epididymis except for a small region in the posterior view. A potential space between the visceral and parietal layers normally haves a few millilitres sterile fluid.

Tunica albuginea lies deep to the tunica vaginalis. Each testis is covered by the tunica albuginea, which helps to maintain its shape and integrity. A testis measured $5 \mathrm{~cm} \times 3 \mathrm{~cm} \times 2 \mathrm{~cm}$ and is homogeneously echogenic in ultrasound. The testicular parenchyma consists of multiple lobules, each of which is composed of several seminiferous tubules that lead via tubuli recti to the dilated spaces known as the rete testis. The epididymis, which overlies the superior and lateral aspects of the testis, is composed of a head, body, and tail. The body of the epididymis courses alongside the testicle inferiorly to become the tail, which continues as the vas deferens in the spermatic cord

\section{DIAGNOSIS}

Initial provisional diagnosis can be formed on basis of patient history alone. Careful history and examination for:

Symptoms: Pain, nausea, vomiting, fainting, scrotal swelling.

Signs: Tenderness, redness, swelling, ecchymosis of the hemiscrotum

The testicles may be displaced to the inguinal region or rarely in to the abdominal cavity ${ }^{6,7}$. 


\section{INVESTIGATIONS}

Standard ultrasound is a sufficient investigation for diagnosis of scrotal injury which is performed lying supine with the scrotum supported by a towel between the thighs. These are the various findings in different conditions:

\section{Testicular Rupture}

The normal tunica albuginea looks as hyperechoic line outlining the testis. The discontinuity of the tunica albuginea suggests rupture of the testis. Sensitivity and specificity of USG for diagnosis of testicular rupture sequentially is $50 \%$ and $75 \%{ }^{8}$

\section{Testicular Fracture}

Testicular fracture in ultrasound shows a linear hypoechoic, avascular area within the testicular parenchyma that may or may not be associated with tunica albuginea rupture ${ }^{9}$.

\section{Hematoma}

Intra-testicular hematoma is common in blunt testicular trauma. This takes time to develop, therefore an acute hematoma is reexamined within 12-24 hours later the initial ultrasound examination to detect any changes in echogenicity ${ }^{10,11}$.

\section{Haematocele}

Accumulations of blood within the tunica vaginalis, are the commonest in the scrotum after blunt trauma ${ }^{10}$. Large haematocele may cause compression of blood vessels and bring down blood flow, mimicking complete or partial torsion. Thus, emergency surgical evacuation of the extra testicular hematoma is necessary to rejuvenate blood flow in a large haematocele. Ultrasound has limited success in diagnosing tunica albuginea rupture in the event of a large hematoma ${ }^{12}$.

\section{Traumatic Epididymitis}

Traumatic epididymitis is uncommon, but it can occur in patients who have sustained acute scrotal trauma.

\section{Testicular Torsion}

Trauma-induced testicular torsion is a well-known phenomenon and a surgical emergency. Traumatic torsion can be induced by stimulating forceful contraction of the Cremaster muscles.

\section{Testicular Dislocation}

Testicular dislocation is uncommon after trauma injury, and it is difficult to diagnose with ultrasound examination after acute trauma.

Color Doppler imaging of scrotum is required for assessing the testicular viability and perfusion. Sometimes testicular MRI or CT scan as second-line imaging modalities may be required when USG is not helpful1.

\section{MANAGEMENT}

\section{Haematocele}

Haematocele is commonest finding in scrotal trauma. It requires conservative as well as surgical management.

Conservative management is recommended for small haematoceles that are up to three times of the size of the contralateral testis ${ }^{13}$.

But conservative management in large haematoceles often needs delayed surgery (> 3 days). These patients with large haematoceles who fails conservative management have a higher chances of orchidectomy than patients who undergo early surgery. ${ }^{14-18}$

Early surgical exploration preserve testis in more than $90 \%$ of cases compared to delayed surgeries which result in orchidectomy in $45-55 \%$ of patients ${ }^{18}$.
Another drawback of conservative management is prolonged hospital stay and may result in infection and subsequent pus formation.

Therefore, large haematoceles must be explored earlier irrespective of the presence of testicular contusion or rupture.

\section{Testicular rupture}

Testicular rupture accounts approximately $50 \%$ of blunt scrotal trauma ${ }^{18}$. It may happen due to traumatic compression of the testis against the inferior pubic ramus or symphysis and thigh. Approximately $50 \mathrm{~kg}$ force is needed to produce testicular rupture (Wasko and Goldstein 1996). ${ }^{19}$

Usually testicular rupture is unilateral, but $1.5 \%$ of cases may be bilateral ${ }^{20}$. In rare instances it is associated with epididymal rupture, which is difficult to detect with ultrasound.

Testicular rupture symptomatically presented with pain, nausea, vomiting, and sometimes fainting. Hemiscrotum would be tender, swollen, and ecchymotic.

\begin{tabular}{ll}
\multicolumn{2}{c}{ AAST organ injury severity scale for the testis } \\
\hline Grade & Description of injury \\
\hline I & Contusion or hematoma \\
II & Subclinical laceration of tunica albuginea \\
III & $\begin{array}{l}\text { Laceration of tunica albuginea with }<50 \% \\
\\
\text { parenchymal loss }\end{array}$ \\
IV & $\begin{array}{l}\text { Major laceration of tunica albuginea with \& } \\
\end{array}$ \\
V & To\% parenchymal loss \\
\hline
\end{tabular}

High-resolution, real-time USG use to diagnosis of intra- and/or extra-testicular haematoma, testicular contusion, or rupture21-28. The colour Doppler study provides information about testicle viability. If scrotal USG is inconclusive, testicular CT or MRI may be helpful29.

When imaging studies are inconclusive then surgical exploration is ideal to exclude testicular rupture and other injury.

Scrotal exploration includes evacuation of blood clots and haematoma, excision of any necrotic testicular tubules and closure of the tunica albuginea with running absorbable sutures likely $3 / 0$ Vicryl.

More than $80 \%$ of ruptured testes can be salvaged if surgical repair is performed within 72 hours of testicular injury ${ }^{30}$.

\section{Testicular dislocation}

Traumatic testicular dislocation is rare. It is common in road traffic accidents $^{31-33}$. Usually it is unilateral but may be bilateral in $25 \%$ of cases $^{33}$.

Dislocation can be a subcutaneous, in the superficial external inguinal ring, inguinal canal or abdominal cavity.

Traumatic dislocation of the testis is treated by manual replacement and secondary orchidopexy. If primary manual reposition cannot be performed, immediate orchidopexy is indicated.

\section{Penetrating scrotal trauma}

Penetrating injuries are rare to the scrotum require surgical exploration with conservative debridement of non-viable tissue. Primary repair of the testis and scrotum usually performed and also depends on the extent of injury. ${ }^{34}$ 


\begin{tabular}{ll}
\multicolumn{2}{r}{ AAST organ injury severity scale for the scrotum } \\
\hline Grade & Description of injury \\
\hline I & Contusion \\
II & Laceration $<25 \%$ of scrotal diameter \\
III & Laceration $\& 25 \%$ of scrotal diameter \\
IV & Avulsion $<50 \%$ \\
V & Avulsion $\& 50 \%$ \\
\hline
\end{tabular}

Extensive injury of the tunica albuginea is repaired by mobilisation of a free tunica vaginalis flap for testicular closure. But in unstable patients, orchiectomy is indicated.

In the case of extensive loss of genital tissue, e.g. IED blast injury, complex and staged reconstructive surgical procedures are often required 35 .

\section{CASE REPORT}

A 32 year male patient came to the emergency surgery ward with an alleged history of blunt trauma scrotum as a result of hit by a cricket ball one day back. He complained of pain, swelling \& enlargement of right scrotum. He gave no history of any other medical comorbidity.

On clinical examination patient had stable vitals and systemic examination was with in normal limits.

Local examination: right hemiscrotum enlarged in size, skin erythematous, warm, indurated and tender. Testis could not be palpated separately from the swelling, there was no dislocation of testis, cough impulse was negative and getting above swelling was present.

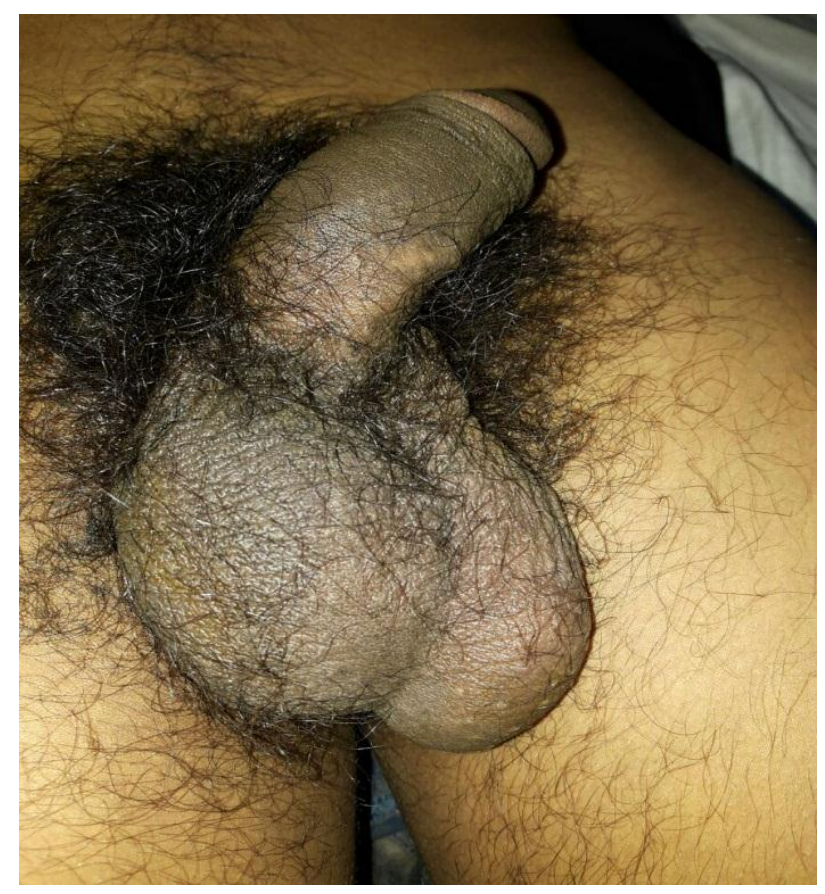

Fig 1: Showing enlarged right scrotum

Different measurement of affected testis comparing with normal one were:

\begin{tabular}{lll}
\hline Measurements & Right & Left \\
\hline Length & $9 \mathrm{~cm}$ & $6 \mathrm{~cm}$ \\
Width & $5.5 \mathrm{~cm}$ & $3.5 \mathrm{~cm}$ \\
Thickness & $5 \mathrm{~cm}$ & $4 \mathrm{~cm}$ \\
\hline
\end{tabular}

All blood investigations were normal. USG inguino-scrotal region suggested mild right scrotal haematocele with scrotal wall hematoma. Both testes had normal vascularity.

On the basis of clinical evaluation and radiological investigation it was known that affected hemiscrotum was less than three times of the normal scrotum and both testes had normal vascularity without any testicular rupture.

Conservative management was planned and patient kept on nonsteroidal analgesic drugs and scrotal support.

Patient discharged was on day five post admission, and follow-up USGs performed on 21 days and 6 weeks post injury that showed healthy and viable bilateral testes.

\section{DISCUSSION}

Blunt scrotal trauma may cause testicular rupture, haematocele, dislocation, and haematoma formation with rupture in approx. $45 \%$ of cases. ${ }^{36}$

Acute scrotal trauma is an uncommon injury because of the scrotal mobility and also testis being protected by tunica albuginea, despite its exposed and hanging location. ${ }^{37}$

Various studies demonstrated that testicular rupture is usually caused by more $50 \mathrm{~kg}$ force against the inferior pubic ramus or the pubic symphysis after blunt scrotal trauma. ${ }^{38}$

USG inguinoscrotal is sufficient investigation for diagnosis of testicular rupture, and if ruptured testis is having more than $30 \%$ intra-testicular haematoma or necrotic tissue then its prognosis is very poor to be salvaged. ${ }^{39}$

European Association of Urology (EAU) recommended that surgical exploration with excision of necrotic tissue and closure of the tunica albuginea is mandatory in each event of testicular rupture. ${ }^{39}$

Testicular dislocation is rarer than rupture and it is to be repositioned urgently with orchidopexy. ${ }^{39}$

At last hematoma or haematocele can be managed conservatively but urgent surgical exploration with extraction of haematoma is recommended when the affected testis is enlarged $>3$ times the contralateral testis. ${ }^{39}$

We have managed our case conservatively without any complication.

\section{CONCLUSION}

Scrotal trauma though is a rare clinical entity but the incidence is growing with industrialisation, advent of adventure sports and increase in motor vehicles. Scrotal and testicular trauma has seen a lot of standardisation through the works of urological and trauma associations, across the globe. We emphasise upon the early detection and management as per set protocols. Use of sonography has also been brought out in our study.

\section{REFERENCES}

1. Buckley JC, McAninch JW (2006) Use of ultrasonography for the diagnosis of testicular injuries in blunt scrotal trauma. J Urol 175:175178

2. Deurdulian C, Mittelstaedt CA, Chong WK, Fielding JR (2007) US of acute scrotal trauma: optimal technique, imaging findings, and management. Radiographics 27:357-369

3. Dogra VS, Gottlieb RH, Oka M, Rubens DJ. Sonography of the scrotum. Radiology 2003; 227:18-36

4. Wasko R, Goldstein AG (1966) Traumatic rupture of the testicle. JUrol 95:721-723. 
5. Deurdulian C, Mittelstaedt CA, Chong WK, Fielding JR. US of acute scrotal trauma: optimal technique, imaging findings, and management. RadioGraphics 2007; 27:357-369

6. Lynch TH, Martínez-Piñeiro L, Plas E, Serafetinides E, Türkeri L, et al. (2005) EAU guidelines on urological trauma. Eur Urol 47: 1-15.

7. Santucci RA, Bartley JM (2010) Urologic trauma guidelines: a 21st century update. Nat Rev Urol 7: 510-519

8. Guichard G, El Ammari J, Del Coro C, et al. Accuracy of ultrasonography in diagnosis of testicular rupture after blunt scrotal trauma. Urology 2008; 71:52-56

9. Blaivas M, Brannam L. Testicular ultrasound. Emerg Med Clin North Am 2004; 22:723-748

10. Bhatt S, Dogra VS. Role of US in testicular and scrotal trauma. RadioGraphics 2008; 28:1617-1629

11. Dogra V, Bhatt S. Acute painful scrotum. Radiol Clin North Am 2004; 42:349-363

12. Aganovic $L$, Cassidy F. Imaging of the scrotum. Radiol Clin North Am 2012; 50:1145-1165

13. Tiguert R, Harb JF, Hurley PM, et al. Management of shotgun injuries to the pelvis and lower genitourinary system. Urology 2000 Feb; 55(2):193-7.

14. Monga M, Hellstrom WJ. Testicular Trauma. Adolesc Med 1996 Feb; 7(1):141-148.

15. McAninch JW, Kahn RI, Jeffrey RB, et al. Major traumatic and septic genital injuries. J Trauma 1984 Apr; 24(4):291-8.

16. Altarac $S$. Management of 53 cases of testicular trauma. Eur Urol 1994; 25(2):119-23.

17. Cass AS, Luxenberg M. Value of early operation in blunt testicular contusion with hematocele. J Urol 1988 Apr; 139(4):746-7.

18. Cass AS, Luxenberg M. Testicular injuries. Urology 1991 Jun; 37(6):528-30.

19. Wasko R, Goldstein AG. Traumatic rupture of the testicle. J Urol 1966 May; 95(5):721-3.

20. Cass AS, Ferrara L, Wolpert J, Lee J. Bilateral testicular injury from external trauma. J Urol 1988; 140:1435-1436

21. Andipa E, Liberopoulos K, Asvestis C. Magnetic resonance imaging and ultrasound evaluation of penile and testicular masses. World J Urol 2004 Nov; 22(5):382-91.

22. Corrales JG, Corbel L, Cipolla B, et al. Accuracy of ultrasound diagnosis after blunt testicular trauma. J Urol 1993Dec;150(6):1834-6.

23. Fournier GR Jr, Laing FC, McAninch JW. Scrotal ultrasonography and the management of testicular trauma. Urol Clin North Am 1989 May; 16(2):377-85.

24. Kratzik C, Hainz A, Kuber W, et al. has ultrasound influenced the therapy concept of blunt scrotal trauma? J Urol 1989 Nov; 142(5):1243-6.

25. Martinez-Piñeiro L Jr, Cerezo E, Cozar JM, et al. Value of testicular ultrasound in the evaluation of blunt scrotal trauma without haematocele. Br J Urol 1992 Mar; 69(3):286-90.
26. Micallef M, Ahmad I, Ramesh N, et al. Ultrasound features of blunt testicular injury. Injury 2001 Jan; 32(1):23-6.

27. Mulhall JP, Gabram SG, Jacobs LM. Emergency management of blunt testicular trauma. Acad Emerg Med 1995 Jul; 2(7):639-43.

28. Patil MG, Onuora VC. The value of ultrasound in the evaluation of patients with blunt scrotal trauma.Injury $1994 \mathrm{Apr} ; 25(3): 177-8$.

29. Muglia V, Tucci S Jr, Elias J Jr, et al. Magnetic resonance imaging of scrotal diseases: when it makes the difference. Urology 2002 Mar; 59(3):419-23.

30. Lupetin AR, King W 3rd, Rich PJ, Lederman RB. The traumatized scrotum: ultrasound evaluation. Radiology 1983; 148:203-207

31. Lee JY, Cass AS, Streitz JM. Traumatic dislocation of testes and bladder rupture. Urology 1992 Dec; 40(6):506-8.

32. Shefi S, Mor Y, Dotan ZA, et al. Traumatic testicular dislocation: a case report and review of published reports. Urology 1999 Oct; 54(4):744.

33. Nagarajan VP, Pranikoff K, Imahori SC, et al. Traumatic dislocation of testis. Urology $1983 \mathrm{Nov}$; 22(5):521-4.

34. Altarac S. A case of testicle replantation. J Urol 1993 Nov; $150(5$ Pt 1):1507-8.

35. Hudak SJ, Hakim S. Operative management of wartime genitourinary injuries at Balad Air Force Theater Hospital, 2005 to 2008. J Urol 2009 Jul; 182(1):180-3.

36. Mulhall JP, Gabram SG, Jacobs LM. Emergency management of blunt testicular trauma. Acad Emerg Med $1995 \mathrm{Jul} ; 2$ 2(7):639e43.

37. van der Horst C, Martinez Portillo FJ, Seif C, Groth W, Junemann KP. Male genital injury: diagnostics and treatment. BJU Int 2004 May; 93(7):927e30.

38. Wasko R, Goldstein AG. Traumatic rupture of the testicle. J Urol 1966 May; 95(5):721e3.

39. Summertom DJ, Djakovic N, Kitrey ND, Kuehhas F, Lumen N, Serafetinidis E. Guidelines on urological trauma. http://www.uroweb.org/gls/pdf/23_Urological_Trauma_LR.pdf [Last accessed May 2014].

\section{Source of Support: Nil. Conflict of Interest: None Declared.}

Copyright: (c) the author(s) and publisher. IJMRP is an official publication of Ibn Sina Academy of Medieval Medicine \& Sciences, registered in 2001 under Indian Trusts Act, 1882.

This is an open access article distributed under the terms of the Creative Commons Attribution Non-commercial License, which permits unrestricted non-commercial use, distribution, and reproduction in any medium, provided the original work is properly cited.

Cite this article as: Devendra K Prajapati, Kapil Rampal, Jyoti M Prajapati. Review of Diagnosis and Management of Scrotal Trauma with a Case Report. Int J Med Res Prof. 2016; 2(3):197-200. 